\title{
The Ameliorative Effect of Adenophorae Radix on Atopic Dermatitis in vivo and in vitro
}

\author{
Ji-Wook Jung and Su-Jin Kim ${ }^{\dagger}$ \\ Department of Herbal Medicinal Pharmacology, College of Herbal Bio-industry, \\ Daegu Haany University, Gyeongsan 712-715, Korea
}

\begin{abstract}
Adenophorae Radix (AR) has been used as a traditional medicine for various diseases. However, the regulatory effects of AR in atopic dermatitis are not yet understood. This study attempted to determine the pharmacological effects of AR and its constituent on both compound $48 / 80$ or histamine-induced scratching behaviors and 2, 4-dinitrochlrobenzene (DNCB)-induced atopic dermatitis in mice. The findings of this study demonstrated that AR reduced compound 48/80 or histamine-induced scratching behaviors in mice. Treatment of AR attenuated the AD symptoms such as eczematous, erythema and dryness and serum IgE and IL-6 levels in AD model. Additionally, AR inhibited the TNF- $\alpha$-induced the Nuclear factor- $\kappa \mathrm{B}$ activation in $\mathrm{HaCaT}$ cells. Collectively, the findings of this study provide us with novel insights into the pharmacological actions of $\mathrm{AR}$ as a potential molecule for therapeutic agent against atopic dermatitis.
\end{abstract}

Key Words: Adenophorae radix, Allergic inflammation, Nuclear factor- $\mathrm{kB}$

\section{INTRODUCTION}

Atopic dermatitis (AD) is a common skin disease characterized by a chronic and relapsing inflammatory dermatitis (Buske-Kirschbaum et al., 2001). AD is known to be the result of an immune system dysregulation, ultimately resulting in allergic inflammation (Gold and Kemp, 2005). The incidence of $\mathrm{AD}$ has increased steadily over recent years. Generally, most therapy for AD is corticosteroids (Berke et al., 2012). However, these long-term treatments cause serious side effects such as immunosuppression, and epidermal barrier dysfunction (Shiohara et al., 2004). Consequently, there is a need for anti-atopic agents that cause fewer side effects.

\footnotetext{
*Received: May 13, 2014 / Revised: September 2, 2014

Accepted: September 8, 2014

${ }^{\dagger}$ Corresponding author: Su-Jin Kim. Department of Herbal Medicinal Pharmacology, College of Herbal Bio-industry, Daegu Haany University, Gyeongsan 712-715, Korea.

Tel: +82-53-819-1389, Fax: +82-53-819-1389

e-mail: ksj1009@dhu.ac.kr

(C) The Korean Society for Biomedical Laboratory Sciences. All rights reserved.
}

Keratinocytes, which are the main epidermal cells, are considered to play a critical role in AD (Eichenfield et al., 2012). Keratinocyte produce inflammatory cytokine and chemokine by various stimulations (Vestergaard et al., 2000). These mediators contribute to the infiltration of inflammatory cells to sites of inflammation in the skin. It was reported that cytokines were expressed at high levels in lesional skin of $\mathrm{AD}$ patients (Homey et al., 2006). Cytokine production is associated with increased activation of the gene transcriptional regulator, nuclear factor-kappa $\mathrm{B}(\mathrm{NF}-\mathrm{\kappa} B)$ in $\mathrm{AD}$ (Choi et al., 2013). Stimulation of keratinocytes with TNF- $\alpha$ leads to activation of $\mathrm{NF}-\kappa \mathrm{B}$ and subsequently increases the expression of inflammatory genes (Lee et al., 2013). An increase in NF- $\kappa \mathrm{B}$ activity associated with the secretion of high levels of inflammatory genes has also been noted in the context of allergic inflammatory responses (Gilmore and Garbati, 2011). The results of those studies demonstrated that NF- $\kappa \mathrm{B}$ activation and the subsequent activation of inflammatory gene expression are critically important in the initiation and perpetuation of allergic inflammation.

Traditional medicine has been the subject of increased 
interest for its potential in the treatment of various diseases. Recently, many studies have been conducted to identify herb medicine effective for treatment of AD (Yang et al., 2013; Chan et al., 2008). Adenophorae Radix (AR) has been used as a traditional medicine for various diseases. Recently, it was reported that AR regulated the inflammation through the suppression of cytokines in asthma (Roh et al., 2008). However, the ameliorative effect and molecular mechanism of AR on atopic dermatitis have not been understood. In the present study, we elucidate whether AR modulates the atopic dermatitis. We attempted to ascertain the pharmacological effects of $\mathrm{AR}$ on both compound $48 / 80$ or histamine-induced scratching behaviors and 2 , 4-dinitrochlrobenzene (DNCB)-induced atopic dermatitis in mice. In an effort to elucidate the effect responsible for AR's anti-atopic effect, we evaluated the effects of AR on the NF- $\kappa \mathrm{B}$ activation in $\mathrm{HaCaT}$ cells.

\section{MATERIALS AND METHODS}

\section{Reagents}

Compound 48/80, histamine, terfenadine, avidin peroxidase (AP) and 1-chloro-2,4-dinitrochlorobenzene (DNCB) were purchased from Sigma Chemical Co. (St. Louis, MO, USA). Roswell Park Memorial Institute (RPMI) 1640 was purchased from Gibco BRL (Grand Island, NY). Fetal bovine serum (FBS) was purchased from Thermo Fisher Scientific Inc. (Somerset, NJ, USA). Anti-mouse IgE, recombinant $\operatorname{IgE}$ and biotinylated $\operatorname{IgE}$ were purchased from Pharmingen (San Diego, CA, USA). NF- $\mathrm{B}$ and histone were purchased from Santa Cruz Biotechnology, Inc. (Santa Cruz, CA).

\section{Animals}

Male ICR mice (4 weeks, 18 20 g) were purchased from the Daehan biolink Co., Ltd. (Chungbuk, Korea). Animals were housed 6 heads per cage, allowed spontaneous take in food and water. Animals were kept under a 12-h light/dark cycle (light on 08:00 20:00) at room temperature (23 \pm $\left.2{ }^{\circ} \mathrm{C}\right)$ and humidity $(55 \pm 10 \%)$. All animal procedures and experiments were approved by the Daegu Haany University of Animal Ethics Committee (approval number
DHU2013-087).

\section{Preparation of AR}

The dried roots of AR were purchased from the Human herb (Gyeongbuk, Korea). The roots (100 g) were chopped using a blender with $1 \mathrm{~L}$ of $70 \%$ aqueous ethanol solution under room temperature for $24 \mathrm{~h}$ and then concentrated under a vacuum. Then the extract solution obtained was filtered, concentrated on a water bath under vacuo, frozen and lyophilized to yield ethanol extracts. The yield of extracts was $16.1 \%$.

\section{Scratching behavioral experiment}

Before the experiment, the ICR mice $(n=6)$ were put into acrylic cages $(22 \times 22 \times 24 \mathrm{~cm})$ for about $30 \mathrm{~min}$ for acclimation. The behavioral experiments were performed according to the method of Sugimoto et al. (1998) The rostral part of the skin on the back of mice was clipped, and compound 48/80 (50 $\mu \mathrm{g} / \mathrm{kg})$ or histamine $(100 \mu \mathrm{g} / \mathrm{kg})$ for each mouse was intradermally injected. The scratching agents were dissolved in tween 80 and then used. Control mice received a tween 80 injection in place of the scratching agent. Immediately after the intradermal injection, the mice (one animal/cage) were put back into the same cage for the observation of scratching. Scratching of the injected site by the hind paws was counted and compared with that of the other sites, such as the ears. Each mouse was used for only one experiment. The mice generally showed several scratches for $1 \mathrm{~s}$, and a series of these behaviors was counted as one incident of scratching for $30 \mathrm{~min}$. AR $(100 \mathrm{mg} / \mathrm{kg})$ and terfenadine $(10 \mathrm{mg} / \mathrm{kg})$ was orally administered $1 \mathrm{~h}$ before the scratching agents.

\section{DNCB-induced atopic dermatitis}

Experiments were conducted in accordance with a previously described protocol. The dorsal skin of the BALB/c mice $(n=6)$ was shaved and treated with a depilatory prior to the experiment. The mice were sensitized with $100 \mu$ of $0.15 \%$ DNCB in acetone-olive oil (3:1) applied to the dorsal skin twice per week for 5 weeks. Control mice received vehicle (acetone/olive oil=3:1). After 3 weeks, AR (100 $\mathrm{mg} / \mathrm{kg}$ ) or terfenadine $(10 \mathrm{mg} / \mathrm{kg})$ was orally administered 
2 weeks until the end of the experiment.

\section{Cell culture}

Human immortalized keratinocytes (HaCaT cells) were cultured in RPMI1640 (100 unit/ml penicillin, $100 \mu \mathrm{g} / \mathrm{ml}$, streptomycin, and $10 \%$ heat-inactivated FBS) at $37^{\circ} \mathrm{C}, 5 \%$ $\mathrm{CO}_{2}$ and $95 \%$ humidity.

\section{IgE assay}

IgE levels in serum were measured by modification of an enzyme-linked immunosorbent assay (ELISA). 96 well plates were coated with $100 \mu$ aliquots of anti-mouse IgE monoclonal Abs at $1.0 \mu \mathrm{g} / \mathrm{ml}$ in PBS at $\mathrm{pH} 7.4$ and were incubated overnight at $4{ }^{\circ} \mathrm{C}$. After additional washes, $100 \mu \mathrm{l}$ of sample and $\operatorname{IgE}$ standards were added and incubated at $37^{\circ} \mathrm{C}$ for $2 \mathrm{~h}$. After $2 \mathrm{~h}$ incubation at $37^{\circ} \mathrm{C}$, the wells were washed and then $0.2 \mu \mathrm{g} / \mathrm{ml}$ of biotinylated anti- mouse $\operatorname{IgE}$ was added and again incubated at $37^{\circ} \mathrm{C}$ for $2 \mathrm{~h}$. After washing the wells, AP was added and plates were incubated for $30 \mathrm{~min}$ at $37^{\circ} \mathrm{C}$. Wells were again washed and ABTS substrate was added. Color development was measured at $405 \mathrm{~nm}$ using an automated microplate ELISA reader. A standard curve was run on each assay plate using recombinant $\operatorname{IgE}$ in serial dilutions.

\section{Preparation of nuclear extract}

Nuclear and cytoplasmic extracts were prepared as described previously (Schoonbroodt et al., 1997). Briefly, after the cells were washed with ice-cold phosphate-buffered saline (PBS). These cells were resuspended in $60 \mu \mathrm{l}$ of buffer A (10 mM Hepes/KOH, $2 \mathrm{mM} \mathrm{MgCl}_{2}, 0.1 \mathrm{mM}$ EDTA, $10 \mathrm{mM} \mathrm{KCl,} 1 \mathrm{mM}$ DTT, and $0.5 \mathrm{mM}$ PMSF, pH 7.9). The cells were allowed to swell on ice for $15 \mathrm{~min}$, lysed gently with $2.5 \mu \mathrm{l}$ of $10 \%$ Nonide P (NP)-40, and centrifuged at $2,000 \times \mathrm{g}$ for $10 \mathrm{~min}$ at $4{ }^{\circ} \mathrm{C}$. The supernatant was collected and used as the cytoplasmic extracts. The nuclei pellet was resuspended in $40 \mu \mathrm{l}$ of buffer B (50 mM HEPES/KOH, $50 \mathrm{mM} \mathrm{KCl,} 300 \mathrm{mM} \mathrm{NaCl}, 0.1 \mathrm{mM}$ EDTA, $10 \%$ glycerol, $1 \mathrm{mM}$ DTT, and $0.5 \mathrm{mM}$ PMSF, $\mathrm{pH}$ 7.9), left on ice for $20 \mathrm{~min}$, inverted and the nuclear debris was spun down at $15,000 \times \mathrm{g}$ for $15 \mathrm{~min}$ to remove nuclear debris. The supernatant (nuclear extract) was collected, frozen in liquid nitrogen and stored at $-70^{\circ} \mathrm{C}$ until ready for analysis.

\section{Western blot analysis}

The isolated protein was mixed with an equal volume of $2 \times$ SDS sample buffer, boiled for $5 \mathrm{~min}$ and then separated through a $10 \%$ denaturing protein gel. After electrophoresis, the protein was transferred to nylon membranes by electrophoretic transfer. The membranes were blocked in $5 \%$ skim milk for $2 \mathrm{~h}$, rinsed and incubated overnight at $4{ }^{\circ} \mathrm{C}$ with primary antibodies. After three washes in PBST/0.1\% Tween 20, the membranes were incubated for $1 \mathrm{~h}$ with HRP-conjugated secondary antibodies. After three washes in PBST $/ 0.1 \%$ Tween 20, the antibody-specific proteins were visualized using an enhanced chemiluminesence detection system according to the recommended procedure (Amersham Corp. Newark, NJ, USA). The quantity of protein was evaluated by using a bicinchoninic acid (BCA) protein assay (Sigma. st. Louis, MO, USA).

\section{Statistical analysis}

The experiments were shown a summary of the data from at least-three experiments and presented as the mean \pm S.D. Statistical evaluation of the results was performed by independent $t$-test. A value of $P<0.05$ was considered statistically significant.

\section{RESULTS}

\section{Effect of AR on compound 48/80 or histamine - induced scratching behaviors in mice}

The anti-scratching behavior effects of AR were investigated on the compound 48/80-induced scratching behavior animal model. When the AR was orally administered $1 \mathrm{~h}$ before compound 48/80 injections, the scratching behaviors were reduced. The inhibition rate of AR $(100 \mathrm{mg} / \mathrm{kg})$ was approximately $43.5 \%$ (Fig. 1A). Additionally, we investigated the contribution of AR in histamine-induced scratching behavior. As shown in Fig. 1B, orally administered AR inhibited the histamine-induced the scratching behaviors. The maximal rates of histamine-induced scratching behavior inhibition by AR (100 mg/kg) were approximately $39.50 \%$. 
A

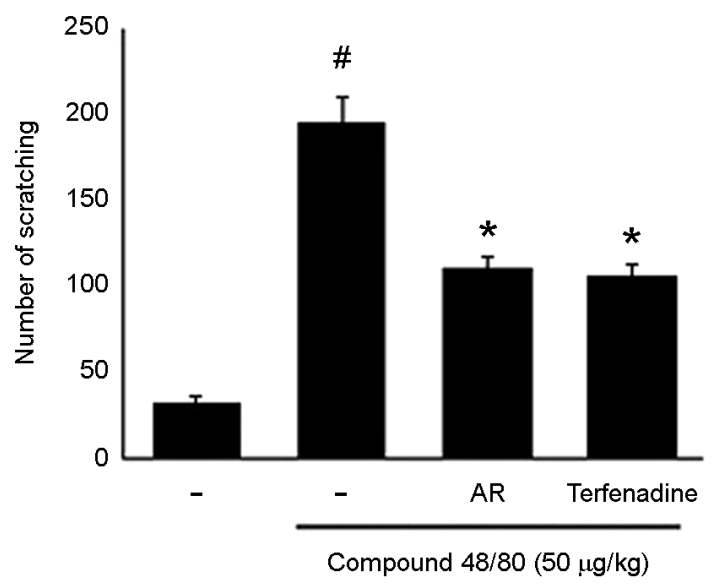

B

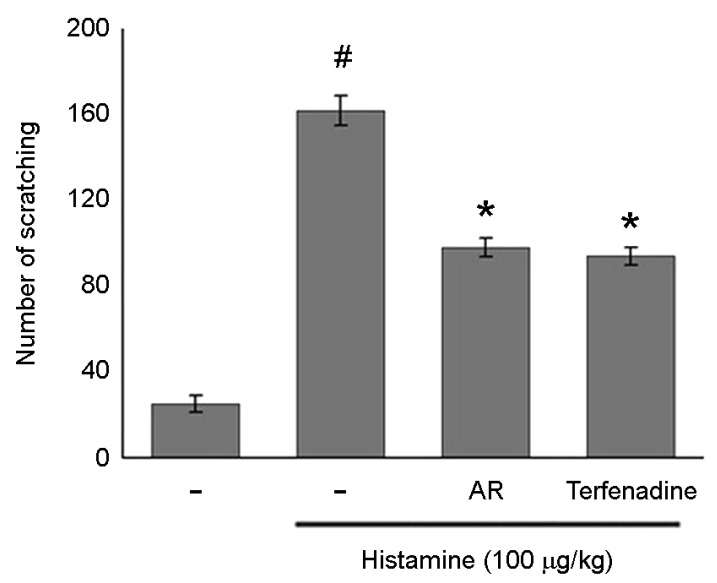

Fig. 1. The effect of AR on compound 48/80 or histamine-induced scratching behavior in ICR mice. Each datum represents the means \pm S.D. of three independent experiments $\left({ }^{\sharp} P<0.05\right.$ vs. control group, ${ }^{*} P<0.05$ vs. compound $48 / 80$-treated group).

Terfenadine was used as a positive control in this study.

\section{Effect of AR on DNCB-induced atopic dermatitis and IgE levels in serum}

In order to evaluate the regulatory effects of $\mathrm{AR}$ in an atopic dermatitis in vivo model, DNCB was administered to BALB/c mice. As shown in Fig. 2A, when mice were treated for 2 weeks with AR, the atopic dermatitis was recovered to a significant extent. To evaluate the effects of AR on IgE levels in serum, blood samples were collected. The levels of IgE were measured via ELISA. The results showed that IgE levels were increased as the result of DNCB exposure, but this phenomenon was significantly
A

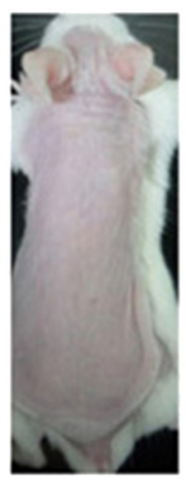

Control

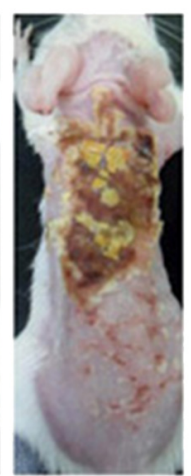

DNCB

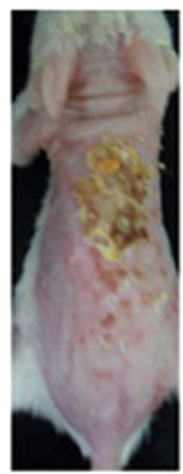

$\mathrm{DNCB}+\mathrm{AR}$

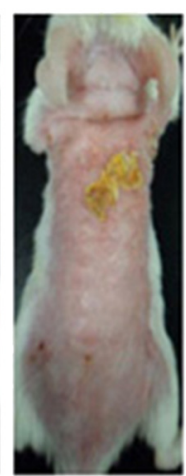

DNCB+Terf
B

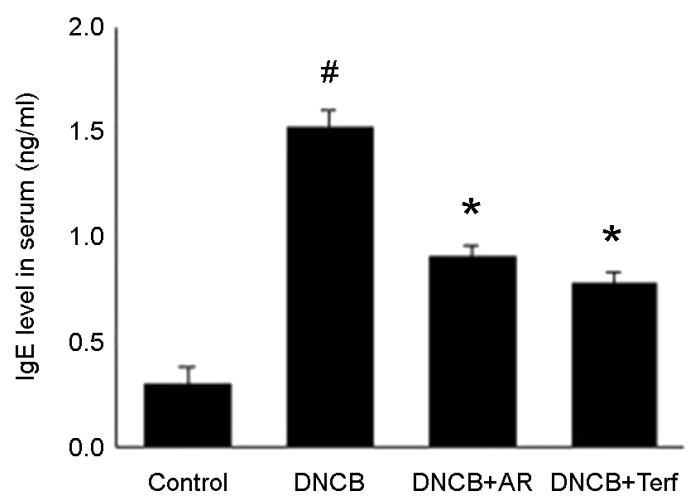

Fig. 2. The effect of AR on the DNCB-induced dermatitis (A) and serum IgE levels (B). Each datum represents the means \pm S.D. of three independent experiments $\left({ }^{\sharp} P<0.05\right.$ vs. control group, ${ }^{*} P<$ 0.05 vs. DNCB-treated group).

reduced in the AR group (Fig. 2B).

\section{Effect of AR on NF-кB activation in HacaT cells}

As the suppression of NF- $\mathrm{kB}$ activation has been linked with anti-allergy reaction, we speculated that the effects of AR might be mediated, at least in part, via the regulation of $\mathrm{NF}-\mathrm{\kappa B}$ pathway. Because NF- $\mathrm{kB}$ activation requires nuclear translocation of the RelA/p65 subunit of NF- $\mathrm{kB}$, we examined the effect of AR on the nuclear pool of Rel A/p65 protein by western blot analysis. As shown in Fig. $3 \mathrm{~A}$, TNF- $\alpha$ plus IFN- $\chi$ considerably increased the nuclear Rel A/p65 protein level, indicating nuclear translocation of Rel A/p65. Pretreatment of AR inhibited the increase of the nuclear Rel A/p65 levels. The relative level of NF- $\mathrm{kB}$ was represented in Fig. 3B. 

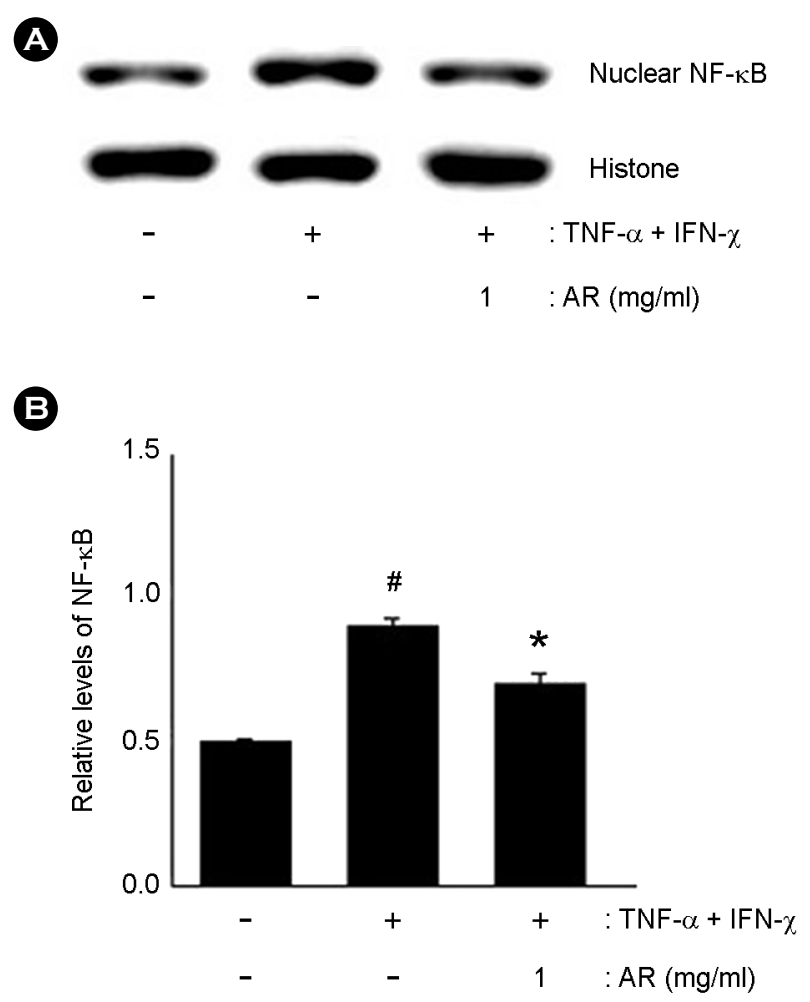

Fig. 3. The effect of AR on the NF- $\mathrm{kB}$ activation in HaCaT cells. Cells were pre-treated with AR $(1 \mathrm{mg} / \mathrm{ml})$ for $1 \mathrm{~h}$ and then stimulated with TNF- $\alpha+\mathrm{IFN}-\chi$ for $1 \mathrm{~h}$. All data were represented in the mean \pm S.D. of triplicate determinations from triplicate separate experiments $\left({ }^{\#} P<0.05\right.$ vs. control, ${ }^{*} P<0.05$ vs. TNF- $\alpha+$ IFN- $\chi$ alone).

\section{Effect of AR on IL-6 levels and NF- $\mathrm{BB}$ activation in DNCB-treated mice}

We investigated the effect of AR on IL-6 levels in the tissues. At the end of experiment, the skin tissues were homogenized, and ELISA was performed. As shown in Fig. $4 \mathrm{~A}$, the levels of IL-6 were significantly increased in the skin tissues of DNCB-treated mice compared to that of control. However, administration of AR reduced these induction induced by DNCB. Additionally, we determine the effect of AR on NF- $\mathrm{BB}$ activation. The results showed that treatment of $\mathrm{AR}$ attenuated the NF- $\mathrm{KB}$ activation in DNCB-treated skin tissue (Fig. 4B).

\section{DISCUSSION}

Although herbal medicines have been used to treat the allergic diseases, the pharmacologic mechanisms of most

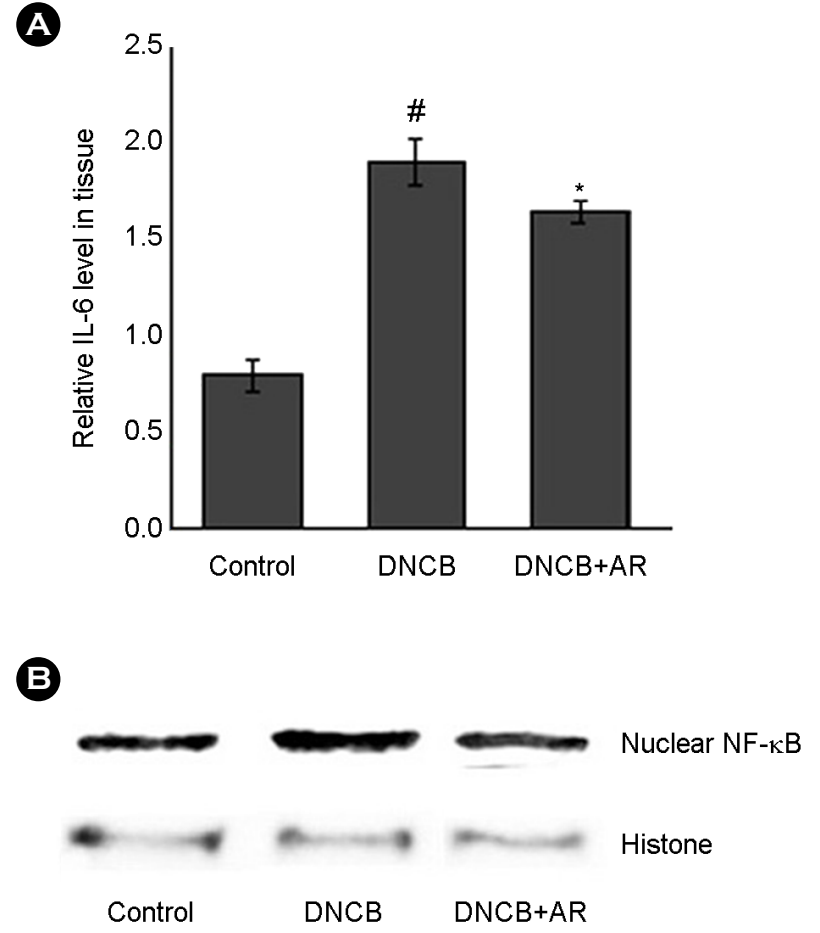

Fig. 4. The effect of $A R$ on the IL-6 levels and NF- $\kappa B$ activation in DNCB-treated mice. (A) The levels of IL-6 in skin tissue were measured. (B) Nuclear extracts in skin tissues were prepared and evaluated for RelA/p65 via Western blot analysis $\left({ }^{\#} P<0.05\right.$ vs. control group, ${ }^{*} P<0.05$ vs. DNCB-treated group).

herbal medicines have not been understood. In this study, we demonstrated that effects and molecular mechanisms of AR on atopic dermatitis. The findings of this study showed that AR attenuated the compound $48 / 80$ or histamineinduced scratching behaviors and inhibited DNCB-induced atopic dermatitis under in vivo conditions. Additionally, AR inhibited the activation of NF- $\mathrm{BB}$ in $\mathrm{HaCaT}$ cells.

$\mathrm{AD}$ is a chronic inflammatory skin disease and is characterized by erythema, edema, and scaling (Leung and Bieber, 2003). Generally, steroid therapy is a crucial factor in the treatment of $\mathrm{AD}$, but it cannot be administered over the long-term, owing to its deleterious side-effects. Therefore, several researchers have attempted to find a new drug, which is effective in the treatment of AD (Shiohara et al., 2004). The $\mathrm{AD}$ was characterized by a potent skin inflammation associated with an elevated level of $\operatorname{IgE}$ against many types of allergens (Allam and Novak, 2006; Brenninkmeijer et al., 2008). On the base of these studies, we have focused to 
evaluate the effects of $\mathrm{AR}$ on DNCB-induced allergic reactions in vivo. The findings of this study revealed that $\mathrm{AR}$ significantly reduced the $\mathrm{AD}$ symptoms such as eczematous, erythema and dryness. Additionally, AR caused a reduction in IgE levels in serum induced by DNCB. These results demonstrate AR's potential effect on antiatopic responses via the regulation of $\operatorname{IgE}$ levels.

In pathological skin conditions, histamine is involved in the induction of itching and edema (Minami and Kamei, 2004). This study focused on the manner in which AR regulate the scratching behaviors in mice. In this study, we showed that AR inhibited the compound 48/80 or histamineinduced scratching behaviors in mice.

The production of inflammatory mediators is associated with increased activation of the gene transcription regulators NF-kB (Zhang et al., 2014). After a variety of stimuli, the I $\mathrm{B}$ proteins are phosphorylated, and degraded, allowing for NF- $\kappa \mathrm{B}$ to translocate into the nucleus where it can bind specific DNA sequences located in the promoter regions of target genes and activate gene transcription, thereby indicating its pivotal function in the regulation of inflammatory responses, via the control of the transcription of inflammatory cytokine genes. From this, inhibition of NF$\kappa \mathrm{B}$ activation has been suggested as an anti-inflammatory strategy in $\mathrm{AD}$. Therefore, we attempted to determine whether the anti-inflammatory effect of AR is through the regulation of $\mathrm{NF}-\mathrm{\kappa B}$ activation. The results demonstrated that $\mathrm{AR}$ inhibited the NF- $\mathrm{KB}$ translocation into nucleus in stimulated HaCaT cell. Therefore, we hypothesized that AR might exert anti-inflammatory effects via NF- $\kappa B$ activation. Although AR attenuated the activation of NF- $\kappa B$, the effect of $\mathrm{AR}$ on the pathways involving NF- $\mathrm{KB}$ (phosphorylation of IKB- $\alpha$ and IKK activation) was not determined. Therefore, further studies will be necessary in order to clarify more precisely the role of AR on the NF- $\kappa B$ pathway.

In conclusion, AR can regulate the allergy response in vivo, including in compound $48 / 80$ or histamine-induced scratching behaviors and DNCB-induced atopic dermatitis. Additionally, we demonstrated in this study that the antiinflammatory activities of AR could be attributed, at least in part, to the inhibition of $\mathrm{NF}-\kappa \mathrm{B}$ in $\mathrm{HaCaT}$ cell. Our study may provide a basis for the therapeutic use of $A R$ in inflammatory skin diseases.

\section{Acknowledgements}

This research was supported by Basic Science Research Program through the National Research Foundation of Korea (NRF) funded by the Ministry of Education, Science and Technology (2011-0022703).

\section{REFERENCES}

Allam JP, Novak N. The pathophysiology of atopic eczema. Clin Exp Dermatol. 2006. 31: 89-93.

Brenninkmeijer EE, Spuls PI, Legierse CM, Lindeboom R, Smitt $\mathrm{JH}$, Bos JD. Clinical differences between atopic and atopiform dermatitis. J Am Acad Dermatol. 2008. 58: 407-414.

Berke R, Singh A, Guralnick M. Atopic dermatitis: an overview. Am Fam Physician. 2012. 86: 35-42.

Buske-Kirschbaum A, Geiben A, Hellhammer D. Psychobiological aspects of atopic dermatitis: an overview. Psychother Psychosom. 2001. 70: 6-16.

Chan BC, Hon KL, Leung PC, Sam SW, Fung KP, Lee MY, Lau HY. Traditional Chinese medicine for atopic eczema: PentaHerbs formula suppresses inflammatory mediators release from mast cells. J Ethnopharmacol. 2008. 120: 85-91.

Choi JH, Jin SW, Park BH, Kim HG, Khanal T, Han HJ, Hwang YP, Choi JM, Chung YC, Hwang SK, Jeong TC, Jeong HG. Cultivated ginseng inhibits 2,4-dinitrochlorobenzene-induced atopic dermatitis-like skin lesions in NC/Nga mice and TNF- $\alpha /$ IFN- $\gamma$-induced TARC activation in HaCaT cells. Food Chem Toxicol. 2013. 56: 195-203.

Eichenfield LF, Ellis CN, Mancini AJ, Paller AS, Simpson EL. Atopic dermatitis: epidemiology and pathogenesis update. Semin Cutan Med Surg. 2012. 31: 3-5.

Gilmore TD, Garbati MR. Inhibition of NF- $\mathrm{B}$ signaling as a strategy in disease therapy. Curr Top Microbio Immunol. 2011. 349: 245-263.

Gold MS, Kemp AS. Atopic disease in childhood. Med J Aust. 2005. 182: 298-304.

Homey B, Steinhoff M, Ruzicka T, Leung DY. Cytokines and chemokines orchestrate atopic skin inflammation. J Aller Clin Immunol. 2006. 118: 178-189.

Leung DY, Bieber T. Atopic dermatitis. Lancet. 2003. 361: 151-160.

Lee CS, Jeong EB, Kim YJ, Lee MS, Seo SJ, Park KH, Lee MW. Quercetin-3-O-(2"-galloyl)- $\alpha$-l-rhamnopyranoside inhibits TNF 
$-\alpha$-activated NF-kB-induced inflammatory mediator production by suppressing ERK activation. Int Immunopharmacol. 2013. 16: 481-487.

Minami K, Kamei CA. chronic model for evaluating the itching associated with allergic conjunctivitis in rats. Int Immunopharmacol. 2004. 4: 101-108.

Roh SS, Kim SH, Lee YC, Seo YB. Effects of radix adenophorae and cyclosporine A on an OVA-induced murine model of asthma by suppressing to $T$ cells activity, eosinophilia, and bronchial hyperresponsiveness. Mediators Inflamm. 2008: 781425 .

Schoonbroodt S, Legrand-Poels S, Best-Belpomme M, Piette J. Activation of the NF-kappaB transcription factor in a Tlymphocytic cell line by hypochlorous acid. Biochem J. 1997. 321: 777-785.

Shiohara T, Hayakawa J, Mizukawa Y. Animal models for atopic dermatitis: are they relevant to human disease?. J Dermatol
Sci. 2004. 36: 1-9.

Sugimoto Y, Umakoshi K, Nojiri N, Kamei C. Effect of histamine H1 receptor antagonists on compound 48/80-induced scratching behavior in mice. Eur J Pharmacol. 1998. 351: 1-5.

Yang G, Choi CH, Lee K, Lee M, Ham I, Choi HY. Effects of Catalpa ovata stem bark on atopic dermatitis-like skin lesions in NC/Nga mice. J Ethnopharmacol. 2013. 30: 145: 416-423.

Vestergaard C, Bang K, Gesser B, Yoneyama H, Matsushima K, Larsen CG. A Th2 chemokine, TARC, produced by keratinocytes may recruit CLA+CCR4+lymphocytes into lesional atopic dermatitis skin. J Invest Dermatol. 2000. 115: 640-646.

Zhang M, Zhou J, Wang L, Li B, Guo J, Guan X, Han Q, Zhang

H. Caffeic acid reduces cutaneous tumor necrosis factor alpha (TNF- $\alpha$ ), IL-6 and IL-1 $\beta$ levels and ameliorates skin edema in acute and chronic model of cutaneous inflammation in mice. Biol Pharm Bull. 2014. 37: 347-354. 